\title{
Electrocoagulation/electroflotation Process Applied to Decolourization of a Solution Containing the Dye Yellow Sirius K-CF
}

\author{
Manoel V. B. Gonçalves, Stela C. De Oliveira, Bruna M. P. N. Abreu, Elidia M. Guerra and \\ Dane T. Cestarolli* \\ Universidade Federal de São João del Rei, Campus Alto Paraopeba, Rod. Mg 443, Km 7, Ouro \\ Branco, MG, Brazil \\ *E-mail: dane.cestarolli@ufsj.edu.br
}

doi: $10.20964 / 2016.09 .42$

Received: 14 March 2016 / Accepted: 16 June 2016 / Published: 7 August 2016

\begin{abstract}
In the present work, the electrocoagulation/electroflotation process using aluminum electrode was applied for decolourization of solutions containing the dye yellow Sirius K-CF in aqueous media. The experiments were performed for synthetic solutions focusing the effect of following operational parameters on the efficiency dye coloration removal: electrocoagulation time process, applied potential, initial $\mathrm{pH}$, initial dye concentration and initial concentration of $\mathrm{NaCl}$ used as supporting electrolyte in aqueous media. The main results were: increasing time results in increasing of efficiency of dye yellow Sirius K-CF color removal; the best initial pHs are 3 and 5; the better applied potential is 7.0 V , beyond which no effective improvement may be achieved. It was also observed that lower dye concentrations provide better color removal rates. It was verified an increase in concentration of the electrolyte did not provide better efficiency on the EC process. In the best parameters investigated, high efficiency was observed, reaching more than $95 \%$ of decolourization,
\end{abstract}

Keywords: electrocoagulation $\cdot$ dye $\cdot$ textile industry $\cdot$ wastewater treatment

\section{FULL TEXT}

(C) 2016 The Authors. Published by ESG (www.electrochemsci.org). This article is an open access article distributed under the terms and conditions of the Creative Commons Attribution license (http://creativecommons.org/licenses/by/4.0/). 